\title{
Spray dried aqueous extract of Orthosiphon aristatus Blume (Java tea)
}

\author{
Malvis Robaina-Mesa1, Oreste Dario López-Hernández ${ }^{2}$, Jorge Enrique Rodríguez-Chanfrau ${ }^{3 *}$, \\ Antonio Nogueira-Mendoza ${ }^{4}$
}

\begin{abstract}
${ }^{1}$ Instituto Superior de Tecnologías y Ciencias Aplicadas (INSTEC), La Habana, Cuba, ${ }^{2}$ Facultad de Ciencias e Ingeniería de Alimentos, Universidad Técnica de Ambato, Ecuador, ${ }^{3}$ Facultad de Química, Universidad de la Habana, La Habana, Cuba, ${ }^{4}$ Centro de Investigación y Desarrollo de Medicamentos, La Habana, Cuba
\end{abstract}

\begin{abstract}
Orthosiphon aristatus (Lamiaceae) is an herb medicinal found mainly in China, Indian and South East Asia. The purpose of this work was to develop a technological process for obtaining dry extract of Orthosiphon aristatus by spray dry. A process for the obtaining of dry extract from aqueous extract of Orthosiphon aristatus was studied. Response Surface Methodology experimental design was applied to evaluate the effects of inlet and outlet air temperature on drying yield (\%). Mixture experimental design was applied to evaluate the drying adjuvant - total solids relation. Maltodextrin was evaluated as drying adjuvant. The best results were obtained when applying an inlet temperature of $120^{\circ} \mathrm{C}$ and outlet temperature of $80^{\circ} \mathrm{C}$ and a drying adjuvant - total solids relation (w/w) of 60:40. Under these conditions it was demonstrated that the process is reproducible scale studied.
\end{abstract}

Keywords: Orthosiphon aristatus/extract. Spray dry/process. Drying adjuvant. Reflux method. Experimental design.

\section{INTRODUCTION}

Orthosiphon aristatus (Lamiaceae) is an herb medicinal found mainly in China, Indian and South East Asia (Suddee, Paton, Parnell, 2005). In Cuba, this species was introduced in the 70's of the last century. Its useful part is the foliage which is used as a dry drug and fluid extract (Robaina Mesa, Rodriguez-Chanfrau, Nogueira Mendonza, 2016), and its oral administration. Preclinical studies showed the diuretic effect of aqueous extract. Furthermore, it has been reported that the average effective dose was $200 \mathrm{mg} / \mathrm{kg}$ for the aqueous extract. While the acute oral toxicity study showed that doses of $2000 \mathrm{mg} /$ kg not cause toxicity (León-Padilla et al., 1996; Ramos Ruiz, Villaescusa Gonzalez, Vizoso Parra, 1996).

In the last decade, the industrial manufacturing of phytomedicine has grown considerably (Couto et al., 2011). Because of this, transforming a natural raw material into a product suitable for industrial use and further

*Correspondence: C.J.E. Rodríguez Chanfrau. Facultad de Química, Universidad de La Habana, Zapata entre G y Carlitos Aguirres, CP 10400 - Vedado, La Habana, Cuba. E-mail: jerodriguez354@gmail.com therapeutic application it has become a necessity. Several studies on Orthosiphon aristatus have been reported. However, no studies on the preparation dry extract by spray dry have been reported. The purpose of this work was to develop a technological process for obtaining dry extract of Orthosiphon aristatus by spray dry.

\section{MATERIALS AND METHODS}

\section{Vegetal material}

Orthosiphon aristatus Blume from the Experimental Station of Medicinal Plants Dr Juan Tomas Roig (Artemisa province, Cuba) was collected (Cuba, 1983; 1992). Herbarium specimens, voucher ROIG 4632, have been deposited in herbaria at the Experimental Station. The plant material was dried in a solar dryer (SEC SOL-4 equipment, Cuba) for $72 \mathrm{~h}$ and grinded (MANESTY equipment, Italia) to smaller particle size of $100 \mu \mathrm{m}$.

\section{Obtaining concentrated aqueous extracts}

Figure 1 show the procedure used in obtaining 
concentrated aqueous extracts. Stainless steel reactor (stirred tank type) $20 \mathrm{~L}$ capacity, marine propeller stirrer and heating system and gas extraction was used. Solvent drug ratio 1:20 (w/v) and volume $10 \mathrm{~L}$ was used. The extract was filtered under vacuum and concentrated until total solids greater than $10 \%$. Three batches were prepared and evaluated according to the technique of quality control. (Rodríguez-Chanfrau, Castellano, 2012).

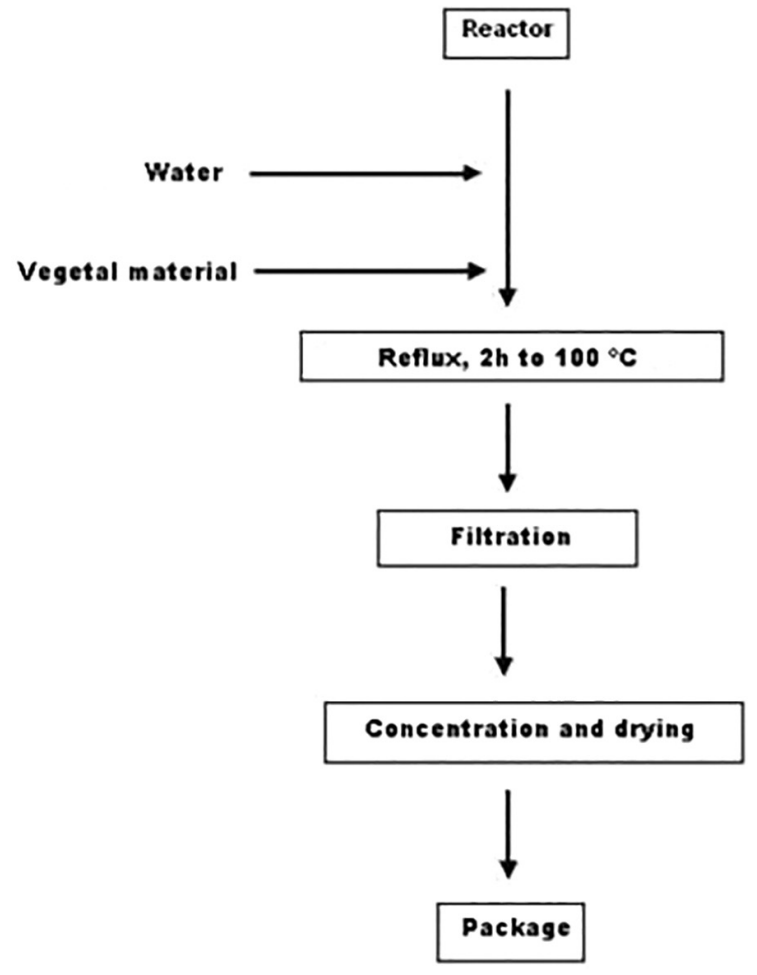

FIGURE 1 - Technological process diagram.

\section{Technological development process}

\section{Establishment of drying parameters}

Response Surface Methodology (RSM) with a $3^{2}$ central composed experimental design replicated in the center point (Statgraphics plus 5.1, USA) was applied to evaluate the effects of inlet air temperature $\left(\mathrm{X}_{1}\right)$ and outlet air temperature $\left(\mathrm{X}_{2}\right)$ on drying yield $(\%)$. The coded independent variables used are listed in Table I. The levels of independent parameters were based on preliminary experimental results. Nine experiments were performed.

The concentrated aqueous extracts were drying in a Buchi B 191 model spray dryer (Switzerland). Inter and outlet air temperatures were carried out according to the experimental design. The product was fed into the spray dryer at room temperature $600 \mathrm{~L} / \mathrm{h}$; the rate was varied to regulated exit air temperature at the desired value. The powder in plastic bags was placed.
TABLE I - Code levels of independent variables used in the response surface methodology design

\begin{tabular}{lccc}
\hline Independent & \multicolumn{3}{c}{ Coded levels } \\
\cline { 2 - 4 } variables & Low & Medium & High \\
\hline $\mathbf{X}_{1}$ & 100 & 140 & 160 \\
$\mathbf{X}_{2}$ & 60 & 80 & 100 \\
\hline
\end{tabular}

\section{Establishment of the concentration of drying adjuvant}

Due to the adhesion of the product on the wall of the chamber was necessary to use $10 \mathrm{DE}$ Maltodextrin (Arancia-cpc, Mexico) as drying adjuvant. Mixture design was studied. Five experiences with the following drying adjuvant - total solids relation: 0.9 : $0.1 ; 0.6: 0.4 ; 0.5: 0.5$; 0.3: 0.7 and 01.0 were evaluated. The carried solution was prepared by dissolving the drying adjuvant in $1 \mathrm{~L}$ of aqueous extract under constant stirring before spray drying. The concentrated aqueous extracts under similar conditions to that described above were spray dried.

Drying efficiency was assessed by determining the total powder content obtained in the process and comparing it with the theoretical powder content that can be obtained. Three batches (10 L scale) with the inert additive were prepared and drying efficiency was determined.

\section{Statistical analysis}

Experimental design, data analysis and optimization procedure were performed using Statgraphic plus 5.1 (USA). Results were considered significant when $\mathrm{p}<0.05$.

\section{RESULTS}

Table II shows the results of the characterization of the concentrated aqueous extracts batch. In all cases dark, transparent liquid amber was obtained. The process yields were above $85 \%$.

Figure 2 show the Pareto chart for the response variable. A significant influence of the dryer temperatures was observed ( $p=0,0018$ y $p=0,0466$ for inlet air temperature and outlet air temperature, respectively). The best yields $(75,2 \pm 0,00)$ were obtained at $120^{\circ} \mathrm{C}$ and 80 ${ }^{\circ} \mathrm{C}$ for inter air temperature and outlet air temperature, respectively. The relationship between the two variables does not significantly influence $(\mathrm{p}=0.0837)$. This behavior is described by the following model equation: 
TABLE II - Analytical results from the batch of aqueous extracts

\begin{tabular}{|c|c|c|c|c|}
\hline Assay & & Results & & Quality limits \\
\hline Batch & 1 & 2 & 3 & \\
\hline Relative density & 0,992 & 0,995 & 0,992 & $\begin{array}{c}\text { Between } 0,990 \text { and } \\
1,050\end{array}$ \\
\hline Total solids & 8,6 & 9,4 & 8,8 & Minimum 8,0\% \\
\hline pH & 5,5 & 5,4 & 5,5 & Between 5,0 and 6,0 \\
\hline Microbial count & $\begin{array}{l}\text { CT: } 100 \\
\text { CH: }<10\end{array}$ & $\begin{array}{l}\text { CT: } 1000 \\
\text { CH: }<10\end{array}$ & $\begin{array}{l}\text { CT: } 100 \\
\text { CH: }<10\end{array}$ & $\begin{array}{c}\text { TC: } 10^{4} \mathrm{CFU} / \mathrm{g} \\
\text { HC: } 10^{3} \mathrm{CFU} / \mathrm{g} \\
\text { Absence of pathogens }\end{array}$ \\
\hline
\end{tabular}

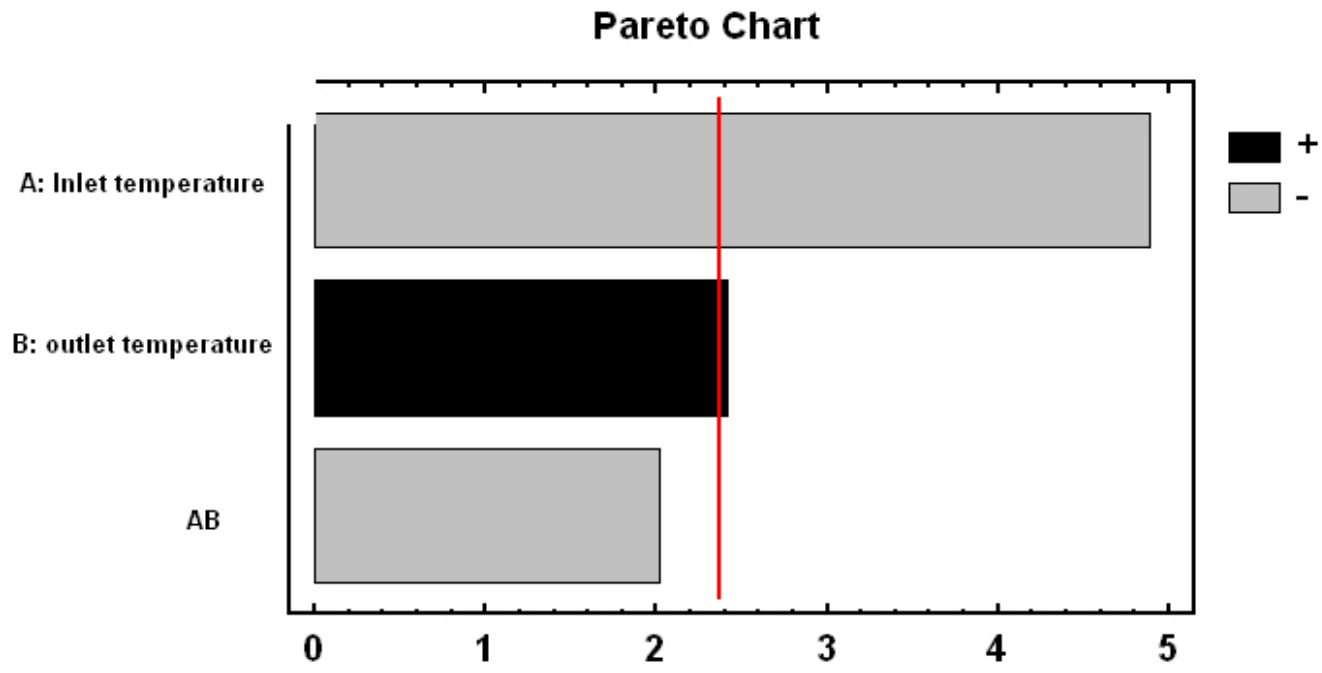

FIGURE 2 - Pareto chart. Yields $(\%)=71,99-16,44 X_{1}+10,41 X_{2}$
$\left(r=0,98 ; r^{2}=0,97\right)$

As can be seen in Table III, the best yields were attained with a maltodextrin - total solid ration between 0,6 and 0,9 . In this range significant differences were not observed. The yields obtained are consistent with the scale of work used (bench scale).

Three batches (10 L scale) with a maltodextrin -

TABLE III - Study results drying adjuvant - total solids relation (Similar letter no significant for $\mathrm{p}<0.05$ )

\begin{tabular}{cc}
\hline $\begin{array}{c}\text { Drying adjuvant - total solids } \\
\text { relation (w/w) }\end{array}$ & Yield (\%) \\
\hline $\mathbf{0 , 9 : 0 , 1}$ & $90,9 \mathrm{a}$ \\
$\mathbf{0 , 6 : 0 , 4}$ & $91,8 \mathrm{a}$ \\
$\mathbf{0 , 5 : 0 , 5}$ & $89,3 \mathrm{~b}$ \\
$\mathbf{0 , 3 : 0 , 7}$ & $83,6 \mathrm{c}$ \\
$\mathbf{0 : 1 , 0}$ & $75,2 \mathrm{~d}$ \\
\hline
\end{tabular}

total solid ration of 60:40 were prepared. Yields above $89 \%$ were obtained. In this condition, a significant difference was not observed (Table IV).

TABLE IV - Results of spray dried product (Similar letter no significant for $\mathrm{p}<0.05$ )

\begin{tabular}{cc}
\hline Batch & Yield (\%) \\
\hline $\mathbf{1}$ & $90,3 \mathrm{a}$ \\
$\mathbf{2}$ & $89,5 \mathrm{a}$ \\
$\mathbf{3}$ & $91,2 \mathrm{a}$ \\
\hline
\end{tabular}

\section{DISCUSSION}

The preparation of intermediary products from medicinal plant is an important part of the development of pharmaceutical solid dosage form (Couto et al., 2011; Leuenberger, Lanz, 2005; Muzzio, Shinbot, Glasser, 2002). These allow the safety and efficacy of medicinal products derived from natural sources is guaranteed. 
These are made from plant extract containing metabolites of interest. Transforming an herbal raw material into a product suitable for industrial is a complex operation requiring the use of various technological processes, including the drying of plant extract (Couto et al., 2011). At present, one of the techniques used in the drying of the extract is spray dry due to operational flexibility and affordable cost (Wendel, Celik, 1987).

Spray dried powder has high stability being easy handling and storage. However, may present the disadvantages of being excessively fine, light, poor, or deficient in flow properties and compressibility (Couto et al., 2011). In many cases, the presence of sugars in the extract causes adhesion of the product on the wall of the chamber during the drying process.

Similar problems were observed in this study. The temperatures set on the experimental design allowed for a rapid drying of the extract without affecting its chemical quality. But, product loss was observed by adhesion to the walls of the chamber. Because of these yields were low.

This situation means that yields are low during the drying process. A solution is to use drying adjuvants, which also serve as excipients of pharmaceutical formulation. Excipients are responsible for modifying the physical and chemical properties of a pharmaceutical formulation and must be safe for oral administration (Couto et al., 2011). The possibility of excipient addition in the extract feed is the main factor responsible for the use of spray dry spray for drying extracts obtained from natural sources (Couto et al., 2011; Broadhead, Rouan, Rhodes, 1992).

On the basis that the main objective of this work was to develop a drying process extract of Orthosiphon aristatus extract for later elaboration of solid dosage forms, and knowing that to dry the extract was necessary to use adjuvant drying, it was decided to use maltodextrin as drying adjuvant. This excipient is included in the Food and Drug Administration's Inactive Ingredients Guide, is approved for oral tablets, and capsules (Rowe, Sheskey, Owen, 2004).

As can be see the best yields was obtained when maltodextrin- total solids ratio was 60:40. In this condition, fine dry powder brown color was obtained. Yields are considered good for the scale in which we worked.

In worked scale, no significant differences between batches produced were observed. This result demonstrates that the batches are homogeneous. It also demonstrates the reproducibility of the technology developed.

\section{CONCLUSION}

when applying an inlet temperature of $120^{\circ} \mathrm{C}$ and outlet temperature of $80^{\circ} \mathrm{C}$ and a drying adjuvant - total solids relation (w/w). Under these conditions, it was demonstrated that the process is reproducible scale studied.

\section{REFERENCES}

Broadhead J, Rouan S, Rhodes, C. The spray drying of pharmaceuticals. Drug Dev Ind Pharm. 1992;18(11):1169-1206.

Couto RO, Araujo RR, Tacon LA, Conceição EC, Bara MT, Paula JR, Freitas AP. Development of a phytopharmaceutical intermediate product via spray drying. Drying Technol. 2011;29(6):709-718.

Cuba. Ministerio de Salud Pública. NC 26-8383. Orthosiphon staminneus (té de riñón). La Habana: Ministerio de Salud Pública; 1983.

Cuba. Ministerio de Salud Pública. NRSP 310. Medicamentos de origen vegetal. Droga cruda. Especificaciones generales. Norma Ramal La Habana: Ministerio de Salud Pública; 1992.

León Padilla M, Tillán Capó J, Hernández Rodríguez A, Cadenas Freixas JL, Calzada Alvarez S. Efecto diurético y toxicidad aguda del Orthosiphon aristatus Blume (Té de riñón). Rev Cubana Plant Med. 1996;1(3):26-30.

Leuenberger H, Lanz M. Pharmaceutical powder technology: from art to science: the challenge of the FDA's process analytical technology initiative. Adv Powder Tech. 2005;16(1):3-25.

Muzzio FJ, Shinbot T, Glasser BJ. Powder technology in pharmaceutical industry: the need to catch up fast. Powder Tech. 2002;124(1-2):1-7.

Ramos Ruiz A, Villaescusa González A, Vizoso Parra A. Ausencia de genotoxicidad en extractos fluidos de Ortosiphon aristatus Blume (Te de riñón) y Lepidium virginicum $\mathrm{L}$. (Mastuerzo). Rev Cubana Plant Med. 1996;1(2):38-43.

Robaina Mesa M, Rodríguez Chanfrau JE, Nogueira Mendoza A. Fluid extract of orthosiphon aristatus blume by reflux process to industrial scale. Rev Ciencias Farm Alimentarias. 2016;2(2):1-6.

Rodríguez Chanfrau JE, Castellano L. Te de riñón. Extracto acuoso concentrado. Técnica de análisis, PT 12004. CIDEM. 2012.

In conclusion, the best results were obtained 
Rowe RC, Sheskey PJ, Owen S. Handbook of pharmaceutical excipients. London: Pharmaceutical Press; 2004. 918 p.

Suddee S, Paton AJ, Parnell JAN. Taxonomic Revision of the tribe Ocimeae Dumort (Lamiaceae) in continental South East Asia III. Ociminae. Kew Bull. 2005;60(1):3-75.
Wendel S, Celik M. An overview of spray-drying applications. Pharm Tech. 1987;27:125-156.

Received for publication on $21^{\text {st }}$ September 2016 Accepted for publication on $24^{\text {th }}$ March 2017 